\title{
In-Hospital Outcomes on Patients Submitted to Primary Percutaneous Coronary Intervention Versus Rescue
}

\author{
Fabio Peixoto Ganassinㄲ, Marcelo José de Carvalho Cantarelli², Hélio José Castello Jr. ${ }^{3}$, \\ Rosaly Gonçalves ${ }^{4}$, Evandro Karlo Pracchia Ribeiro ${ }^{5}$, João Batista de Freitas Guimarães ${ }^{6}$, Silvio Gioppato \\ Julio Cesar Francisco Vardi ${ }^{8}$, Leonardo Cao Cambra Almeida ${ }^{9}$, Ednelson Cunha Navarro ${ }^{10}$, \\ Higo Cunha Noronha ${ }^{11}$, Marcelo Mendes Farinazzo ${ }^{12}$, Thomas Conforti ${ }^{13}$, \\ Leonardo dos Santos Coelho ${ }^{14}$, Roberto Simões de Almeida ${ }^{15}$
}

\begin{abstract}
Background: Difficulties to reach centers that offer primary percutaneous coronary intervention $(\mathrm{PCl})$ in a timely manner turn intravenous thrombolysis into the predominant reperfusion mode in patients with ST segment elevation myocardial infarction (STEMI) in Brazil. In this scenario, rescue PCl becomes an important therapeutic option for patients who fail reperfusion. We have compared hospital outcomes of these two PCI modalities in STEMI. Methods: Between August 2006 to October 2012, consecutive patients with STEMI enrolled in the Angiocardio Registry were submitted to primary or rescue $\mathrm{PCl}$. The incidence of in-hospital major adverse cardiac and cerebrovascular events (MACCE) was compared. Results: We evaluated 801 patients undergoing primary $(n=599)$ or rescue $\mathrm{PCl}(\mathrm{n}=202)$. In the rescue $\mathrm{PCl}$ group a lower frequency of thrombi, total occlusions, pre-procedure TIMI 0/1 flow and angiographically detectable collaterals was observed. The use of stents was similar, as well as the procedure success rates $(91.7 \%$ vs $90.6 \% ; P=0.75)$. The incidence of MACCE $(6.3 \%$ vs $6.9 \% ; \mathrm{P}=0.89)$, death $(4 \%$ vs $4 \% ; \mathrm{P}>0.99)$, stroke $(0.3 \%$ vs $0 ; \mathrm{P}=0.99)$ and reinfarction $(2.7 \%$ vs $3 \% ; \mathrm{P}>0.99)$ was not different between groups. In the multivariate analysis, the
\end{abstract}

RESUMO

\section{Desfechos Hospitalares em Pacientes Submetidos a Intervenção Coronária Percutânea Primária versus de Resgate}

Introdução: Dificuldades de acesso em tempo hábil a centros que oferecem intervenção coronária percutânea (ICP) primária fazem com que a trombólise química seja a modalidade de reperfusão predominante em pacientes com infarto com supradesnivelamento do segmento ST (IAMCSST) no Brasil. Nesse cenário, a ICP de resgate torna-se importante opção para pacientes com insucesso na reperfusão. Comparamos os desfechos hospitalares dessas duas modalidades de ICP no IAMCSST. Métodos: Entre agosto de 2006 e outubro de 2012, pacientes consecutivos do Registro Angiocardio, com IAMCSST, foram submetidos à ICP primária ou de resgate. Foi comparada a incidência de eventos cardíacos e cerebrovasculares adversos maiores (ECCAM) hospitalares. Resultados: Avaliamos 801 pacientes submetidos a ICP primária $(n=599)$ ou a ICP de resgate $(n=202)$. No grupo ICP de resgate foi observada menor frequência de trombos, oclusões totais, fluxo TIMI 0/1 pré-procedimento e presença de circulação colateral. O

\footnotetext{
${ }^{1}$ Trainee physician at the Hemodynamics and Interventional Cardiology Services of Hospital Bandeirantes. São Paulo, SP, Brazil.

${ }^{2}$ Doctor. Interventionist cardiologist physician and coordinator of the Hemodynamics and Interventional Cardiology Services of Hospital Bandeirantes. São Paulo, SP, Brazil.

${ }^{3}$ Master. Interventionist cardiologist physician and coordinator of the Hemodynamics and Interventional Cardiology Services of Hospital Bandeirantes. São Paulo, SP, Brazil.

${ }^{4}$ Master. Interventionist cardiologist physician at the Hemodynamics and Interventional Cardiology Services of Hospital Rede D'Or São Luiz - Unidade Anália Franco. São Paulo, SP, Brazil.

${ }^{5}$ Interventionist cardiologist physician at the Hemodynamics and Interventional Cardiology Services of Hospital Bandeirantes. São Paulo, SP, Brazil.

${ }^{6}$ Interventionist cardiologist physician at the Hemodynamics and Interventional Cardiology Services of Hospital Bandeirantes. São Paulo, SP, Brazil.

7 Master. Interventionist cardiologist physician and coordinator of the Hemodynamics and Interventional Cardiology Services of Hospital Vera Cruz. Campinas, SP, Brazil.

${ }^{8}$ Interventionist cardiologist physician at the Hemodynamics and Interventional Cardiology Services of Hospital Bandeirantes. São Paulo, SP, Brazil.

${ }^{9}$ Interventionist cardiologist physician at the Hemodynamics and In-
}

terventional Cardiology Services of Hospital Bandeirantes. São Paulo, SP, Brazil.

${ }_{10}$ Cardiologist physician at the Hemodynamics and Interventional Cardiology Services of Hospital Regional do Vale do Paraíba. Taubaté, SP, Brazil.

11 Interventionist cardiologist physician at the Hemodynamics and Interventional Cardiology Services of Hospital Regional do Vale do Paraíba. Taubaté, SP, Brazil.

${ }^{12}$ Trainee cardiologist physician at the Hemodynamics and Interventional Cardiology Services of Hospital Bandeirantes. São Paulo, SP, Brazil.

${ }^{13}$ Interventionist cardiologist physician at the Hemodynamics and Interventional Cardiology Services of Hospital Vera Cruz. Campinas, SP, Brazil.

${ }^{14}$ Interventionist cardiologist physician at the Hemodynamics and Interventional Cardiology Services of Hospital Bandeirantes. São Paulo, SP, Brazil.

${ }^{15}$ Interventionist cardiologist physician at the Hemodynamics and Interventional Cardiology Services of Hospital Bandeirantes. São Paulo, SP, Brazil.

Correspondence to: Fabio Peixoto Ganassin. Rua Galvão Bueno, 257 - Liberdade - São Paulo, SP, Brazil - CEP 01516-000

E-mail: fganassin@cardiol.br

Received on: 20/3/2013 • Accepted on: 6/4/2013 
presence of dyslipidemia [odds ratio (OR) 2.190, 95\% confidence interval $(95 \% \mathrm{Cl}) 1.14-4.16$; $\mathrm{P}=0.01$ ], Killip class III or IV (OR 7.494, 95\% Cl 3.90-14.31; P < 0.01) and lesions with moderate/severe calcification (OR 2.852, 95\% Cl 1.39-5.62; $\mathrm{P}<0.01)$, were the variables that best explained in-hospital MACCE. Conclusions: In this contemporary registry, rescue and primary $\mathrm{PCl}$ had similar in-hospital results.

DESCRIPTORS: Myocardial infarction. Angioplasty. Stents. Thrombolytic therapy.

A cute myocardial infarction is an important cause of morbidity and mortality throughout the world. In Brazil, in 2010, over 80,000 deaths were recorded from acute ischemic heart syndromes. ${ }^{1}$ Blood flow return, either by chemical thrombolysis or percutaneous coronary intervention $(\mathrm{PCI})$, if performed within the first hours of symptom onset, is considered the best strategy for the treatment of ST-segment elevation myocardial infarction (STEMI), with proven clinical benefits and reduced mortality, to approximately $4 \%$ to $7 \% .^{2-4}$

Primary $\mathrm{PCl}$, despite the evidence of superiority in relation to chemical thrombolysis, ${ }^{5-8}$ with lower rates of major adverse cardiac and cerebrovascular events (MACCE) and higher rates of patency in the culprit vessel, is not widely available in Brazil. Difficulties to reach hospitals that provide the intervention within a timely manner result in a relatively low number of primary PCls in this country. It is estimated by the Department of Informatics of the Brazilian Unified Health System (Departamento de Informática do Sistema Único de Saúde - DATASUS) that only $13 \%$ to $15 \%$ of hospitalized patients with STEMI receive primary $\mathrm{PCI}$ as a reperfusion strategy. Although data from the National Cardiovascular Intervention Center (Central Nacional de Intervenções Cardiovasculares - CENIC) show a progressive increase in primary $\mathrm{PCls}$ between 2006 and 2010, chemical thrombolysis remains the predominant reperfusion modality, used in over $40 \%$ of patients with STEMI. ${ }^{9}$ Rescue $\mathrm{PCl}$ is mandatory for patients who fail post-fibrinolytic reperfusion (segment resolution $<50 \%$ in 60 minutes), as it reduces the incidence of MACCE, when compared with re-thrombolysis or with conservative treatment. ${ }^{10-12}$

There have been few reports in Brazil comparing primary and rescue $\mathrm{PCl}$ strategies, including the publication by Mattos et al.,13 using data from CENIC between 1997 and 2000, which showed a higher in-hospital mortality for rescue $\mathrm{PCl}$ in a sample in which the use emprego de stents foi similar, assim como a taxa de sucesso do procedimento $(91,7 \%$ vs. $90,6 \% ; P=0,75)$. A incidência de $\operatorname{ECCAM~}(6,3 \%$ vs. $6,9 \%$; $\mathrm{P}=0,89)$, óbito ( $4 \%$ vs. $4 \%$; $\mathrm{P}$ $>0,99)$, acidente vascular cerebral $(0,3 \%$ vs. $0 \%$; $P=0,99)$ e reinfarto $(2,7 \%$ vs. $3 \%$; $P>0,99)$ não diferiu entre os grupos. $\mathrm{Na}$ análise multivariada, dislipidemia (oddsratio [OR] 2,190; intervalo de confiança de 95\% [IC 95\%] 1,14-4,16; P = 0,01], classe funcional Killip III ou IV (OR: 7,494; IC 95\%: $3,90-14,31 ; \mathrm{P}<0,01)$ e lesões com calcificação moderada/ acentuada (OR: 2,852; IC 95\%: 1,39-5,62; $\mathrm{P}<0,01$ ) foram as variáveis que melhor explicaram os ECCAM hospitalares. Conclusões: Neste registro contemporâneo, a ICP de resgate obteve resultados hospitalares similares aos da ICP primária.

DESCRITORES: Infarto do miocárdio. Angioplastia. Stents. Terapia trombolítica.

of coronary stents was restricted to slightly more than half of the studied patients. This study aims at comparing in-hospital outcomes between contemporary primary and rescue $\mathrm{PCl}$ in STEMI.

\section{METHODS}

\section{Patients}

This study included consecutive patients from the Angiocardio registry with STEMI undergoing primary $\mathrm{PCl}$ or rescue PCl, from August 2006 to October 2012. This registry includes all patients undergoing $\mathrm{PCl}$ in Hospital Bandeirantes, Hospital Rede D'Or São Luiz - Unidade Anália Franco, and Hospital Leforte, all located in São Paulo, SP, Brazil; in Hospital Vera Hospital Cruz, Campinas, SP, Brazil; and in Hospital Regional Vale do Paraíba, Taubaté, SP, Brazil.

The clinical and angiographic characteristics were compared, as well as characteristics related to the procedure, rates of success, and incidence of MACCE at discharge. Data were prospectively collected and stored in a computerized database for further analysis.

\section{Percutaneous coronary intervention}

The technique, access route, and choice of material, including the use of thrombus aspiration catheters and glycoprotein IIb/IIla inhibitors during the procedure, were at the discretion of the surgeons. Unfractionated heparin was used at a dose of $70 \mathrm{U} / \mathrm{kgto} 100 \mathrm{U} / \mathrm{kg}$ at the beginning of the procedure, except in patients who were already receiving low molecular-weight heparin. In these cases, a dose of $0.3 \mathrm{mg} / \mathrm{kg}$ was added intravenously, adjusted according to the last dose interval. All patients received combined antiplatelet therapy with acetylsalicylic acid (dose of 100 to $200 \mathrm{mg} /$ day) and clopidogrel (loading dose of 300 to $600 \mathrm{mg}$, and maintenance dose of $75 \mathrm{mg} /$ day). 


\section{Angiographic analysis and definitions}

The analyses were performed on at least two orthogonal projections by professionals who had experience with digital quantitative angiography. This study used the same angiographic criteria as CENIC. The American College of Cardiology/American Heart Association criteria were used to identify the type of lesion. ${ }^{4}$ Lesions were considered long when their length was $>20 \mathrm{~mm}$. Thrombolysis in Myocardial Infarction (TIMI) classification was used to classify pre- and post-procedure coronary flow. ${ }^{14}$ The rate of procedural success was defined as attaining angiographic success (residual stenosis $<30 \%$, with TIMI 3 flow) and absence of MACCE, comprising death, stroke, reinfarction, and emergency coronary artery bypass graft (CABG) surgery.
Reinfarction was defined by the presence of new ischemic electrocardiographic changes and/or alterations in laboratory markers of myocardial necrosis and/or angiographic evidence of vessel-target occlusion. The overall mortality was considered for the analysis (death from any cause) during the hospitalization period.

\section{Statistical Analysis}

The data were stored in an Oracle-based Coreangio database, plotted on Excel spread sheets, and analyzed using SPSS software, version 15.0. Continuous variables were expressed as means and standard deviations, and categorical variables as absolute numbers and percentages. The associations between continuous variables were evaluated using the analysis of variance (ANOVA)

TABLE 1

Clinical Characteristics

\begin{tabular}{|c|c|c|c|}
\hline & $\begin{array}{c}\text { Primary } \\
(\mathbf{n}=599)\end{array}$ & $\begin{array}{c}\text { Rescue } \\
(n=202)\end{array}$ & P-value \\
\hline Age, years & $61.3 \pm 13.1$ & $57.9 \pm 11.8$ & $<0.01$ \\
\hline Male gender, n (\%) & $425(71)$ & $143(70.8)$ & $>0.99$ \\
\hline Smoking, n (\%) & $174(29)$ & $67(33.2)$ & 0.31 \\
\hline Arterial hypertension, $\mathrm{n}(\%)$ & $411(68.6)$ & $143(70.8)$ & 0.62 \\
\hline Dyslipidemia, n (\%) & $162(27)$ & $46(22.8)$ & 0.26 \\
\hline Diabetes, n (\%) & $143(23.9)$ & $44(21.8)$ & 0.60 \\
\hline Previous myocardial infarction, $\mathrm{n}(\%)$ & $60(10)$ & $17(8.4)$ & 0.59 \\
\hline Previous coronary artery bypass graft surgery, n (\%) & $26(4.3)$ & $2(1)$ & 0.04 \\
\hline Chronic renal failure, $\mathrm{n}(\%)$ & $12(2)$ & $2(1)$ & 0.52 \\
\hline Previous stroke, n (\%) & $13(2.2)$ & $3(1.5)$ & 0.75 \\
\hline Previous percutaneous coronary intervention, $\mathrm{n}(\%)$ & $91(15.2)$ & $27(13.4)$ & 0.60 \\
\hline Killip, n (\%) & & & 0.05 \\
\hline I & $434(75.5)$ & $112(66.7)$ & \\
\hline II & $77(13.4)$ & $32(19)$ & \\
\hline III & $14(2.4)$ & $9(5.4)$ & \\
\hline IV & $50(8.7)$ & $15(8.9)$ & \\
\hline Acute myocardial infarction location, $\mathrm{n}(\%)$ & & & 0.07 \\
\hline Anterior & $224(39)$ & $83(49.4)$ & \\
\hline Antero-apical & $2(0.3)$ & $4(2.4)$ & \\
\hline Antero-lateral & $51(8.9)$ & $11(6.5)$ & \\
\hline Dorsal & $3(0.5)$ & $0(0)$ & \\
\hline Inferior & $194(33.7)$ & $49(29.2)$ & \\
\hline Infero-dorsal & $41(7.1)$ & $5(3)$ & \\
\hline Infero-lateral-dorsal & $52(9)$ & $13(7.7)$ & \\
\hline Lateral & $8(1.4)$ & $3(1.8)$ & \\
\hline
\end{tabular}


TABLE 2

Angiographic characteristics

\begin{tabular}{|c|c|c|c|}
\hline & $\begin{array}{c}\text { Primary }(n=599 \\
\text { pacients } / n=664 \\
\text { vessels/ } n=719 \text { lesions }\end{array}$ & $\begin{array}{c}\text { Rescue }(n=202 \\
\text { pacients } / n=218 \\
\text { vessels/ } n=242 \text { lesions }\end{array}$ & P-value \\
\hline Coronary disease extent, n (\%) & & & 0.49 \\
\hline One-vessel & $496(82.8)$ & $171(84.7)$ & \\
\hline Two-vessel & $88(14.7)$ & $23(11.4)$ & \\
\hline Three-vessel & $13(2.2)$ & $7(3.5)$ & \\
\hline Multivessel & $2(0.3)$ & $1(0.5)$ & \\
\hline Treated vessels, n (\%) & & & 0.03 \\
\hline Left anterior descending artery & $314(47.3)$ & $123(56.4)$ & \\
\hline Left circumflex artery & $99(14.9)$ & $20(9.2)$ & \\
\hline Right coronary artery & $236(35.5)$ & $73(33.5)$ & \\
\hline Left main coronary artery & $3(0.5)$ & 0 & \\
\hline Grafts & $12(1.8)$ & $2(0.9)$ & \\
\hline Type B2/C lesions, n (\%) & $483(78.3)$ & $149(72)$ & 0.07 \\
\hline Calcified lesions, n (\%) & $365(50.9)$ & $113(46.7)$ & 0.29 \\
\hline Moderate/severe calcification, n (\%) & $105(14.6)$ & $25(10.3)$ & 0.11 \\
\hline Thrombotic lesions, n (\%) & $329(45.8)$ & $77(31.8)$ & $<0.01$ \\
\hline Lesions $>20$ mm, n (\%) & $84(11.7)$ & $25(10.3)$ & 0.64 \\
\hline Bifurcation lesions, n (\%) & $51(7.1)$ & $11(4.5)$ & 0.21 \\
\hline Total occlusions, n (\%) & $445(61.9)$ & $92(38)$ & $<0.01$ \\
\hline Pre-procedure TIMI, n (\%) & & & $<0.01$ \\
\hline $0 / 1$ & $487(67.7)$ & $98(40.5)$ & \\
\hline $2 / 3$ & $232(32.3)$ & $144(59.5)$ & \\
\hline Collateral circulation, $\mathrm{n}(\%)$ & $206(28.7)$ & $39(16.1)$ & $<0.01$ \\
\hline
\end{tabular}

model. The associations between categorical variables were evaluated by chi-squared test, Fisher's exact test, or likelihood ratio, when appropriate. Significance level was set at $P<0.05$. Multivariate analysis was used to identify independent predictors of MACCE.

\section{RESULTS}

The present study evaluated 801 consecutive patients who underwent primary $\mathrm{PCl}(\mathrm{n}=599$ patients; 664 vessels; 719 lesions) or rescue $\mathrm{PCl}(\mathrm{n}=202$; patients; 218 vessels; 242 lesions). The rescue $\mathrm{PCl}$ group was, on average, three years younger and had a lower incidence of prior revascularization surgery $(4.3 \%$ vs. $1 \% ; P=0.04)$. There was a tendency in this group of patients to have more advanced Killip class $(P=0.05)$ and higher incidence of anterior wall myocardial infarction $(P=0.07)$. The groups did not differ regarding the other clinical characteristics (Table 1).
Regarding the angiographic characteristics, a strong predominance of patients with one-vessel involvement (> $80 \%$ ) was observed; the left anterior descending artery was the most often affected vessel, especially in the rescue $\mathrm{PCI}$ group (47.3\% vs. 56.4\%). Lower frequency of lesions with thrombi $(45.8 \%$ vs. $31.8 \%$; $\mathrm{P}<0.01)$; total occlusions (61.9\% vs. 38\%; P $<0.01)$; pre-procedure TIMI flow $0 / 1(67.7 \%$ vs. $40.5 \%)$, and the presence of collateral circulation $(28.7 \%$ vs. $16.1 \%$; $\mathrm{P}<0.01)$ was observed in patients undergoing rescue $\mathrm{PCl}$ (Table 2).

Regarding the characteristics of the procedures (Table 3$)$, the rates of stent use were similar $(83.1 \%$ vs. $84.9 \%, P=0.62$ ), with a low rate of drug-eluting stent (DES) use, especially in the rescue $\mathrm{PCI}$ group (7.1\% vs. 1.6\%; $\mathrm{P}=0.01)$. Direct stenting was also more frequent in this group $(24.3 \%$ vs. $44.3 \%$; $\mathrm{P}<$ 0.01). Shorter stents were implanted in the rescue $\mathrm{PCl}$ group (20.8 mm vs. $19.5 \mathrm{~mm}, \mathrm{P}=0.01)$, with no differences between groups regarding stent diameter. 
TABLE 3

Characteristics of procedures

\begin{tabular}{|c|c|c|c|}
\hline & $\begin{array}{c}\text { Primary }(n=599 \\
\text { pacients } / n=664 \\
\text { vessels/ } n=719 \text { lesions }\end{array}$ & $\begin{array}{c}\text { Rescue }(n=202 \\
\text { pacients } / n=218 \\
\text { vessels/ } n=242 \text { lesions }\end{array}$ & P-value \\
\hline Treated vessels/patient & $1.20 \pm 0.48$ & $1.20 \pm 0.51$ & 0.92 \\
\hline Implanted stents, n (\%) & $513(85.6)$ & $175(86.6)$ & 0.81 \\
\hline Stent/patient ratio, n (\%) & $1.06 \pm 0.62$ & $1.00 \pm 0.54$ & 0.24 \\
\hline Stent use, n (\%) & $552(83.1)$ & $185(84.3)$ & 0.62 \\
\hline Drug-eluting stents, n (\%) & $39(7.1)$ & $3(1.6)$ & 0.01 \\
\hline Direct-stenting technique, n (\%) & $134(24.3)$ & $82(44.3)$ & $<0.01$ \\
\hline Stent diameter, mm & $3.09 \pm 0.48$ & $3.13 \pm 0.46$ & 0.27 \\
\hline Stent length, $\mathrm{mm}$ & $20.8 \pm 6.8$ & $19.5 \pm 6.5$ & 0.01 \\
\hline Glycoprotein IIb/IIla inhibitors, n (\%) & $190(68.3)$ & $8(4)$ & $<0.01$ \\
\hline Thromboaspiration, n (\%) & $112(21.8)$ & $10(5.7)$ & $<0.01$ \\
\hline Post-procedure TIMI flow, n (\%) & & & 0.18 \\
\hline $0 / 1$ & $38(5.5)$ & $19(8.3)$ & \\
\hline $2 / 3$ & $652(94.5)$ & $211(91.7)$ & \\
\hline \multicolumn{4}{|l|}{ Degree of stenosis, $\%$} \\
\hline Pre & $95.2 \pm 10.4$ & $90.7 \pm 12.4$ & $<0.01$ \\
\hline Post & $7.3 \pm 22.8$ & $9.1 \pm 26.4$ & 0.36 \\
\hline Procedural success & $549(91.7)$ & $183(90.6)$ & 0.75 \\
\hline
\end{tabular}

A lower degree of pre-procedure lesion stenosis was also observed in this same group $(95.2 \%$ vs. 90.7\%; $\mathrm{P}<0.01$ ), and glycoprotein IIb/IIla inhibitors were used less frequently $(68.3 \%$ vs. $4 \% ; \mathrm{P}<0.01)$, as well as thrombus aspiration catheters $(21.8 \%$ vs. $5.7 \%$; $\mathrm{P}<$ $0.01)$. The procedure success rates were similar and $>$ $90 \%$ in both groups.

The incidence of MACCE $(6.3 \%$ vs. $6.9 \% ; \mathrm{P}=$ $0.89)$, in-hospital death ( $4 \%$ vs. $4 \% ; P>0.99)$, stroke $(0.3 \%$ vs. $0 ; P=0.99)$, and reinfarction $(2.7 \%$ vs. $3 \%$; $P>0.99)$ did not differ between the groups. There were no cases of emergency CABG in the sample (Table 4).

In the univariate analysis, the variables age, smoking, dyslipidemia, presence of lesions with moderate/ severe calcification, prior $\mathrm{CABG}$, chronic renal failure, Killip class III or IV, and use of IIb/IIla glycoprotein inhibitors showed a significant association with the occurrence of MACCE. In the multivariate analysis, the presence of dyslipidemia (odds ratio [OR], 2.190; $95 \%$ confidence interval [95\% Cl], 1.14 to 4.16 ; $\mathrm{P}=0.01$ ], Killip functional class III or IV $(\mathrm{OR}, 7.494 ; 95 \% \mathrm{Cl}$, 3.90 to $14.31 ; \mathrm{P}<0.01$ ), and lesions with moderate/ severe calcification $(\mathrm{OR}, 2.852 ; 95 \% \mathrm{Cl}, 1.39$ to 5.62 ; $\mathrm{P}<0.01)$ were the variables that best explained the presence of in-hospital MACCE (Table 5).

\section{DISCUSSION}

This study compared in-hospital outcomes between contemporary primary and rescue $\mathrm{PCI}$ in STEMI. The findings showed that the occurrence of MACCE was low and similar between groups, with an in-hospital mortality rate of $4 \%$. Similar mortality rates have been recently published in the Strategic Reperfusion (With Tenecteplase and Antithrombotic Treatment) Early After Myocardial Infarction (STREAM) study in patients with less than three hours of STEMI symptom onset submitted to primary $\mathrm{PCl}$ strategy or to pharmaco invasive strategy with the use of tenecteplase and transfer to $\mathrm{PCI}(4.4 \%$ and $4.6 \%$, respectively). ${ }^{14}$

Previous reports have demonstrated higher mortality $(6 \%$ to $8 \%)$ in patients undergoing rescue $\mathrm{PCl}$ in relation to primary $\mathrm{PCl} .{ }^{13,15,16}$ In Brazil, Mattos et al., ${ }^{13}$ with data collected from the CENIC registry, evaluated 9,371 patients and also demonstrated higher mortality of rescue $\mathrm{PCl}$ compared with primary $\mathrm{PCl}(7.4 \%$ vs. $5.6 \%$; $\mathrm{P}=0.034)$. Conversely, Baer et al. ${ }^{17}$ showed similar results between the two modalities, concluding that the rescue intervention is the mandatory procedure for the treatment of STEMI, when chemical thrombolysis failure occurs. It is noteworthy that these publications showed a low rate of stenting $(<60 \%)$ compared 
TABLE 4

In-hospital clinical outcomes

\begin{tabular}{lccc}
\hline & Primary & Rescue & \\
$(\mathbf{n = 5 9 9 )}$ & 202) & P-value \\
\hline Major adverse cardiac and cerebrovascular events, $\mathrm{n}(\%)$ & $38(6.3)$ & $14(6.9)$ & 0.89 \\
In-hospital death, $\mathrm{n}(\%)$ & $24(4)$ & $8(4)$ & $>0.99$ \\
Stroke, n (\%) & $2(0.3)$ & 0 & 0.99 \\
Reinfarction, n (\%) & $16(2.7)$ & $6(3)$ & $>0.99$ \\
\hline
\end{tabular}

TABLE 5

Independent predictors of in-hospital major adverse cardiac and cerebrovascular events after PCI

\begin{tabular}{lccc}
\hline Factors & P-value & OR & 95\% CI \\
\hline Moderate/severe calcification & $<0.01$ & 2.852 & {$[1.39 ; 5.62]$} \\
Dyslipidemia & 0.01 & 2.190 & {$[1.14 ; 4.16]$} \\
Killip (III-IV) & $<0.01$ & 7.494 & {$[3.90 ; 14.31]$} \\
\hline
\end{tabular}

95\% Cl, 95\% Confidence Interval; OR, odds ratio.

to current rates of contemporary $\mathrm{PCl}$. In the present series, the use of stenting in both groups occurred in over $80 \%$ patients. Previous studies have shown that stenting (DES and BMS) favourably affects the prognosis of patients with STEMI, promoting TIMI coronary flow improvement, with lower rates of ventricular dysfunction and mortality. ${ }^{18-20}$

Previous use of fibrinolytics in the rescue $\mathrm{PCl}$ group probably explains the lower thrombotic burden of the lesions and lower frequency of catheter use for thrombus aspiration and glycoprotein IIb/IIla inhibitors, in addition to the decreased use of the direct stenting technique in the present sample. It also explains the higher incidence of TIMI 2/3 before the procedure, which is associated with better prognosis in patients with STEMI. ${ }^{21,22}$ The Plasminogen-activator - Angioplasty Compatibility Trial (PACT), ${ }^{23}$ which compared patients who received rt-PA at a dose of $50 \mathrm{mg}$ or placebo prior to catheterization, showed a higher rate of patency of the vessel pre- $\mathrm{PCI}$ in the group receiving thrombolytic therapy, with increased left ventricular function preservation. The STREAM${ }^{14}$ study also showed higher pre-PCI TIMI 3 flow rates in patients previously submitted to thrombolysis (pharmaco invasive strategy).

Known predictors of failure and worse prognosis of $\mathrm{PCl}$ for myocardial infarction, the moderate/severe coronary calcification, and Killip class III or IV, next to a history of dyslipidemia, were the factors that best explained the occurrence of MACCE in this study. ${ }^{2-4,24}$ Among them, the presence of more advanced Killip functional class raised the risk of MACCE by more than seven-fold.
Rescue $\mathrm{PCl}$, unlike primary $\mathrm{PCl}$, requires further studies to assess its contemporary results; however, in the present registry, it was shown to be a viable alternative for patients that did not have access to primary $\mathrm{PCl}$ and those who failed thrombolytic therapy.

\section{Study limitations}

Limitations to the present study are the retrospective analysis of data between two cohorts with non-adjusted clinical variables and the absence of late follow-up.

\section{CONCLUSIONS}

In this contemporary registry, rescue $\mathrm{PCl}$ showed similar results to those of in-hospital primary $\mathrm{PCI}$.

\section{CONFLICTS OF INTEREST}

The authors declare no conflicts of interest.

\section{REFERENCES}

1. Brasil. Ministério da Saúde. DATASUS. Informações de saúde [Internet]. [citado 2013 maio 21]. Disponível em: http://www. datasus.gov.br

2. Mattos LA, Lemos Neto PA, Rassi A Jr, Marin-Neto JA, Sousa AGMR, Devito FS, et al. Diretrizes da Sociedade Brasileira de Cardiologia - Intervenção Coronária Percutânea e Métodos Adjuntos Diagnósticos em Cardiologia Intervencionista (II Edição - 2008). Arq Bras Cardiol. 2008;91(6 Supl 1):1-58.

3. European Association for Percutaneous Cardiovascular Interventions; Wijns W, Kolh P, Danchin N, Di Mario C, Falk V, Folliguet $\mathrm{T}$, et al. Guidelines on myocardial revascularization. The Task Force on Myocardial Revascularization of the European Society of Cardiology (ESC) and the European Association for CardioThoracic Surgery (EACTS). Eur Heart J. 2010;31(20):2501-55. 
4. Levine GN, Bates ER, Blankenship JC, Bailey SR, Bittl JA, Cercek B, et al. 2011 ACCF/AHA/SCAI Guideline for Percutaneous Coronary Intervention: a Report of the American College of Cardiology Foundation/American Heart Association Task Force on Practice Guidelines and the Society for Cardiovascular Angiography and Interventions. Circulation. 2011;124(23):e574-651.

5. Widimský P, Groch L, Zelízko M, Aschermann M, Bednár F, Suryapranata $\mathrm{H}$. Multicentre randomized trial comparing transport to primary angioplasty vs immediate thrombolysis vs combined strategy for patients with acute myocardial infarction presenting to a community hospital without a catheterization laboratory. The PRAGUE study. Eur Heart J. 2000;21(10):823-31.

6. Dalby M, Bouzamondo A, Lechat P, Montalescot G. Transfer for primary angioplasty versus immediate thrombolysis in acute myocardial infarction: a meta-analysis. Circulation. 2003;108(15):1809-14.

7. Danchin N, Vaur L, Genès N, Etienne $S$, Angioï M, Ferrières J, et al. Treatment of acute myocardial infarction by primary coronary angioplasty or intravenous thrombolysis in the real world: one-year results from a nationwide French survey. Circulation. 1999;99(20):2639-44.

8. Zijlstra F, Hoorntje JCA, de Boer MJ, Reiffers S, Miedema K, Ottervanger JP, et al. Long-term benefit of primary angioplasty as compared with thrombolytic therapy for acute myocardial infarction. N Engl J Med. 1999;341(19):1413-9.

9. Matte BS, Bergoli LCC, Balvedi JA, Zago AC. Perfil da intervenção coronária percutânea no infarto agudo do miocárdio com supradesnivelamento do segmento ST no Brasil de 2006 a 2010: Registro CENIC. Rev Bras Cardiol Invasiva. 2011;19(2):131-7.

10. Gershlick AH, Stephens-Lloyd A, Hughes S, Abrams KR, Stevens SE, Uren NG, et al. Rescue angioplasty after failed thrombolytic therapy for acute myocardial infarction. N Engl J Med. 2005;353(26):2758-68.

11. Wijeysundera HC, Vijayaraghavan R, Nallamothu BK, Foody JM, Krumholz HM, Phillips CO, et al. Rescue angioplasty or repeat fibrinolysis after failed fibrinolytic therapy for ST-segment myocardial infarction: a meta-analysis of randomized trials. J Am Coll Cardiol. 2007;49(4):422-30.

12. Moraes ERFL, Carvalho ACC. Angioplastia de resgate no infarto agudo do miocárdio. Rev Bras Cardiol Invasiva. 2007;15(4):400-7.

13. Mattos LA, Sousa AGMR, Pinto IMF, Silva ER, Carneiro JK, Sousa JE, et al. Uma comparação entre a intervenção coronariana percutânea de resgate e primária realizadas no infarto agudo do miocárdio: relato multicêntrico de 9.371 pacientes. Arq Bras Cardiol. 2004;82(5):434-9.

14. Armstrong PW, Gershlick AH, Goldstein P, Wilcox R, DanaysT, Lambert $\mathrm{Y}$, et al. Fibrinolysis or primary $\mathrm{PCl}$ in ST-segment elevation myocardial infarction. N Engl J Med. 2013;368(15):1379-87.
15. Abbottsmith CW, Topol EJ, George BS, Stack RS, Kereiakes DJ, Candela RJ, et al. Fate of patients with acute myocardial infarction with patency of the infarct-related vessel achieved with successful thrombolysis versus rescue angioplasty. J Am Coll Cardiol. 1990;16(4):770-8.

16. Ross AM, Lundergan CF, Rohrbeck SC, Boyle DH, Brand M, Buller $\mathrm{CH}$, et al. Rescue angioplasty after failed thrombolysis: technical and clinical outcomes in a large thrombolysis trial. GUSTO-1 Angiographic Investigators. J Am Coll Cardiol. 1998;31(7):1511-7.

17. Bär F, Vainer J, Stevenhagen J, Neven K, Aalbregt R, Ophuis TO, et al. Ten-year experience with early angioplasty in 759 patients with acute myocardial infarction. J Am Coll Cardiol.2000;36(1):51-8.

18. Magalhães MA, Brito Jr. FS, Almeida BO, Abizaid A, Gomes I, Nascimento TC, et al. Comparação dos stents farmacológicos vs. stents convencionais para o tratamento do infarto agudo do miocárdio com supradesnivelamento do segmento-ST: resultados do Registro EINSTEIN. Rev Bras Cardiol Invasiva.2008;16(3):279-88.

19. Akasaka T, Yoshida K, Kawamoto T, Kaji S, Ueda Y, Yamamuro A, et al. Relation of phasic coronary flow velocity characteristics with TIMI perfusion grade and myocardial recovery after primary percutaneous transluminal coronary angioplasty and rescue stenting. Circulation. 2000;101(20):2361-7.

20. Stone GW, Brodie BR, Griffin J, Costantini C, Morice MC, St Goar FG, et al. Clinical and angiographic follow-up after primary stenting in acute myocardial infarction: the Primary Angioplasty in Myocardial Infarction (PAMI) stent pilot trial. Circulation. 1999;99(24):1548-54.

21. TIMI Study Group. The Thrombolysis in Myocardial Infarction (TIMI) trial. Phase I findings. N Engl J Med. 1985;312(14):932-6.

22. Stone GW, Cox D, Garcia E, Brodie BR, Morice MC, Griffin J, et al. Normal flow (TIMI-3) before mechanical reperfusion therapy is an independent determinant of survival in acute myocardial infarction: analysis from the primary angioplasty in myocardial infarction trials. Circulation. 2001;104(6): 636-41.

23. Ross AM, Coyne KS, Reiner JS, Greenhouse SW, Fink C, Frey A, et al. A randomized trial comparing primary angioplasty with a strategy of short-acting thrombolysis and immediate planned rescue angioplasty in acute myocardial infarction:the PACT trial. J Am Coll Cardiol. 1999;34(7);1954-62.

24. Sposito AC, Caramelli B, Fonseca FAH, Bertolami MC, Rassi A Jr, et al.; Sociedade Brasileira de Cardiologia. Departamento de Aterosclerose. IV Diretriz Brasileira sobre Dislipidemias e Prevenção da Aterosclerose. Arq Bras Cardiol. 2007;88 Supl1:1-19. 